\title{
Effect of Herd Characteristics, Management Practices, and Season on Different Categories of the Herd Somatic Cell Count
}

\author{
J. J. Lievaart, ${ }^{11,2}$ H. W. Barkema,† W. D. J. Kremer, ${ }^{\star}$ J. van den Broek, ${ }^{\star}$ J. H. M. Verheijden, ${ }^{*}$ \\ and J. A. P. Heesterbeek* \\ ${ }^{*}$ Department of Farm Animal Health, Faculty of Veterinary Medicine, University of Utrecht, Utrecht, the Netherlands \\ †Department of Production Animal Health, Faculty of Veterinary Medicine, University of Calgary, Calgary, Alberta, Canada
}

\begin{abstract}
In this study, the contribution of management practices, herd characteristics, and seasonal variables to the herd somatic cell count (SCC) was quantified in herds with low $(<150,000$ cells $/ \mathrm{mL})$, medium $(150,000$ $200,000$ cell $\mathrm{s} / \mathrm{mL})$, and high $(>200,000$ cells $/ \mathrm{mL}$ ) herd SCC (HSCC). Selection of the variables was performed using a linear mixed effect model; HSCC was calculated as the arithmetic mean of the individual cow's SCC. The data concerning management practices were derived from 3 questionnaires on mastitis prevention and management practices on 246 Dutch dairy farms. The monthly Dairy Herd Improvement test data of these 246 farms were used to calculate the herd characteristics and seasonal effects. None of the management practices were associated with HSCC in all 3 HSCC categories. Some variables only had a significant association with HSCC in one HSCC category, such as dry premilking treatment $(-9,100$ cells $/ \mathrm{mL}$ in the low HSCC category) or feeding calves with high SCC milk (11,100 cells/ $\mathrm{mL}$ in the medium HSCC category). Others had an opposite effect on HSCC in different HSCC categories, such as average parity $(-6,400$ and 11,000 cells $/ \mathrm{mL}$ in the low and medium HSCC category, respectively) and feeding calves with fresh milk (10,300 and $-9,700$ cells/ $\mathrm{mL}$ in the low and high HSCC category, respectively). We conclude that, given the individual Dairy Herd Improvement data and information on management practices of an individual farm, it is possible to provide quantitative insight into the contribution of these different variables to the HSCC of an individual farm. Being able to provide such insight is a prerequisite for interpretation, prediction, and control of HSCC on individual dairy farms.
\end{abstract}

Received December 15, 2006.

Accepted May 9, 2007.

${ }^{1}$ Corresponding author: jlievaart@csu.edu.au

${ }^{2}$ Current address: Charles Sturt University, Wagga Wagga, New South Wales, Australia.
Key words: herd somatic cell count, season, herd characteristic, management practice

\section{INTRODUCTION}

The herd-level SCC is a result of multifactorial cow factors, management practices, and seasonal fluctuations. Cow factors that influence herd SCC are herd size, average parity, DIM, production category, and breed (De Vliegher et al., 2004; Rodrigues et al., 2005; Sewalem et al., 2006). The pathogen distribution among the herd also influences the level of herd SCC (HSCC); herds that are Staphylococcus aureus-positive in the bulk milk have higher bulk milk SCC (BMSCC) than Staph. aureus-negative herds (Pitkälä et al., 2004; Olde Riekerink et al., 2006). Dry cow treatment, milking technique, postmilking teat disinfection, and antibiotic treatment of clinical mastitis are examples of management factors with a significant effect on BMSCC (Igono et al., 1988; Wilson et al., 1997; Barkema et al., 1998a; Barnouin et al., 2004). Seasonal fluctuations such as the summer peak can also have a major effect but do not occur in all herds (Igono et al., 1988; Green et al., 2006). Ideally one would want to continuously monitor and interpret SCC on the herd level and to detect an increase or decrease in the trend over time (Barkema et al., 1999; Jayarao et al., 2004). Bonus programs are installed such as in many countries and states of the United States, which apply a cut-off value varying from 150,000 to 250,000 cells $/ \mathrm{mL}$ (Sampson, 2006). It is important to know in farms that may exceed a cutoff value what is needed to bring it below the bonus program requirements.

Most of the research done on the association between management practices and herd-level SCC uses BMSCC as the outcome variable (Barkema et al., 1998a). Bulk milk SCC does, however, not always provide a good summary of the SCC situation in the lactating herd (Valde et al., 2005). The average HSCC of all lactating cows is, in that respect, a better parameter (Lievaart et al., 2007). Additionally, when the association between BMSCC and management practices is 
studied most often a linear association is assumed (Goodger et al., 1993; Barkema et al., 1998a), but it is likely that because of a different pathogen distribution management practices have a different effect in herds with a different BMSCC (De Haas et al., 2004).

The interpretation and judgment of the HSCC is essential, but there is still little knowledge about the precise quantitative contributions of the significant variables and possible difference of these quantitative effects on different HSCC categories. Therefore, in this study the contribution of herd characteristics, management practices, and seasonal effects was quantified on a low, medium, and high long-term average HSCC by means of a linear mixed effect (LME) model.

\section{MATERIALS AND METHODS}

\section{Data Collection}

Farms were selected that housed lactating cows in a free-stall barn during the winter, participated in a 3- or 4-weekly milk recording system, had annual production quota between 300,000 and $900,000 \mathrm{~kg}$, and had cows of the Holstein-Friesian or Dutch Friesian breeds. Three questionnaires were conducted to collect information on mastitis prevention and control management practices (Barkema et al., 1998a,b). The Dutch Breeding Organization (NRS, Arnhem, the Netherlands) provided the monthly DHI data per farm for a period of 2.5 consecutive years.

The HSCC was calculated as the arithmetic mean of the individual cows' SCC for each milk recording date (Lievaart et al., 2007). Per farm, the mean from the initial 6 mo was used to divide the farms into 3 HSCC categories: low $(<150,000$ cells $/ \mathrm{mL})$, medium $(150,000$ $200,000$ cells $/ \mathrm{mL})$, and high $(>200,000$ cells $/ \mathrm{mL})$ HSCC. The reason to divide the farms into 3 categories is derived from the used data set of Barkema et al. (1998a,b), which described the difference in management variables related to different categories of BMSCC. In total, 246 farms out of the original 300 farms had a complete data set of milk recording data and questionnaires distributed over 81, 86, and 79 farms with a low, medium, and high mean HSCC, respectively. Because of missing individual SCC data, 54 farms had to be excluded from the study. The remaining $2 \mathrm{yr}$ of HSCC data were used to examine the effect of season, herd characteristics, and management practices on HSCC for each category. From all variables for which information was collected, only those variables that are known from literature to influence SCC were selected (Table 1). Additionally, to examine the influence of the previous HSCC and the within-herd distribution of previous individual SCC data, both variables were included in the category of herd characteristics. To characterize this within-herd distribution, the individual SCC were divided into 4 categories, with the precise cut-off value given in Table 1 . We then specified the distribution at a given recording date as the percentage of individual cows in each category at that date.

\section{Data Handling and Statistical Analysis}

Statistical analyses were performed using R (http:// www.r-project.org/ version 2.2.0; last accessed Oct. 2006). An LME model was designed with HSCC as the dependent variable to assess the contribution of the explanatory variables on HSCC (Pinheiro and Bates, 2000). The explanatory variables in the group's seasonal effects, herd characteristics, and management practices were evaluated. The following LME model represents the basis to test the fit of all variables per HSCC category:

$$
\begin{gathered}
\text { HSCC }=\text { intercept }+\beta_{1} \times \text { seasonal effects } \\
+\beta_{2} \times \text { management practices }+\beta_{3}
\end{gathered}
$$

$\times$ herd characteristics + random effect "herd" $+\varepsilon$.

This model was fitted for each of the 3 HSCC categories (low, medium, and high) separately.

The Akaike information criterion (AIC) was used to select the best fitting LME model (Akaike, 1973) using a backwards-stepwise elimination procedure. This selection criterion was defined as follows: $\mathrm{AIC}=-2(\log$ likelihood) $+2 \mathrm{k}$, where $\mathrm{k}$ is the number of explanatory variables (+ intercept) included in the model. The AIC values were then used to compare a series of LME models, and the model with the lowest AIC was considered to be the best LME model (Akaike, 1973). The elimination of variables stopped when the AIC did not change by more than the absolute number of 2 and had the lowest number of variables included. Therefore, a variable was declared significant if the AIC value of the LME model did not change by more than the absolute number of 2 . Even though variables for which $\beta$ values were significant in the best LME model with the lowest AIC value, there was variation between significant variables in how pronounced their effect was. Finally, we decided to include variables into the final model if the standard error was less than one-half of the $\beta$ value and if they had a clear effect of at least $1 \%$ of the average HSCC in the relevant category. Clear effects had a wide range of importance of up to almost 30,000 cells $/ \mathrm{mL}$, and they could be positive and negative. A random farm effect was used as well as a first-order autoregressive (AR1) correlation structure to model dependence in time. Inclusion of the AR1 structure did lower the AIC value, and therefore it was included in the model. The 
Table 1. Summary of the variables; seasonal factors, herd characteristics, and management practices

\begin{tabular}{ll}
\hline Component & Variables \\
\hline Seasonal factors & Month and year \\
Herd characteristics & Herd size, average DIM, average parity, previous herd SCC, percentage of cows with a SCC 0 to 50, \\
& 51 to 150,151 to 250, and 251 to 500 within the previous recording date \\
Management practices & Size of the property, clipping hair of cows, zero grazing, locked in head gates after milking, dry off \\
& procedure, clinical mastitis checks during dry period, planned length of dry period, presence of calving \\
& pen, udder preparation, postmilking teat disinfection, dry cow treatment, method of treatment of clinical \\
& mastitis, minimal number of antibiotic treatments per clinical mastitis case, registration of clinical \\
& mastitis cases, time after calving milk is added to bulk tank, feeding milk with high SCC, antibiotic \\
& residues, or milk replacer to the young calves \\
\hline
\end{tabular}

variances in the model were allowed to differ for each category. The linear part of the model was used to quantify the significance and the contribution on HSCC per variable. Outliers of the data did not influence the outcome of the models, and the residuals of the models were normally distributed.

\section{RESULTS}

The AIC values of the starting models, including all variables, and the final models with the remaining variables are 8,260.9 vs. 8,236.1 (low HSCC category), $3,529.1$ vs. 3,513.9 (medium HSCC category), and $7,327.9$ vs. 7,288.2 (high HSCC category), respectively.

In each HSCC category, mean HSCC of all farms remained within the predefined limits of that category, except for 2 occasions in the low and medium HSCC category (Figure 1). In March, 5 farms exceeded the predefined limits in the medium category of HSCC, and in August 3 farms within the low category of HSCC, respectively (Figure 1). The highest HSCC value in the high category of HSCC was 593,000 cells/mL. Over the 2 -yr period all HSCC categories had a similar pattern of fluctuation, and the standard deviation per category was roughly constant.

The results of the LME model including all significant variables are presented in Tables 2 to 4 . In the low HSCC category, the monthly contribution had the largest value during May (24,500 cells $/ \mathrm{mL})$ and August (21,000 cells/mL; Table 2; Figure 2). The same held for the medium HSCC category. The months May (27,900 cells $/ \mathrm{mL})$ and July $(22,000$ cells $/ \mathrm{mL})$ demonstrated the largest contribution for the high HSCC category (Table 2 ; Figure 2). The year effect was not significant in the low HSCC category and indicated a significant decrease of 6,900 cells $/ \mathrm{mL}$ and 7,200 cells $/ \mathrm{mL}$ in the second year for the medium and high HSCC category, respectively.

The significant herd characteristics are presented in Table 3. The HSCC increased with increasing average parity in the medium $(11,300$ cells $/ \mathrm{mL})$ and high $(8,400$ cells $/ \mathrm{mL}$ ) HSCC category, but an opposite association $(-6,400$ cells $/ \mathrm{mL})$ was found in the low HSCC category.
Average milk yield and size of the lactating herd were associated in only 2 HSCC categories: HSCC decreased with 900 and 1,200 cells $/ \mathrm{mL}$ per $\mathrm{kg}$ increase in daily milk yield in the medium and high HSCC category, respectively. In the medium and high HSCC categories, HSCC increased with increasing lactating herd size: 200 and 100 cells/mL per head, respectively. Average DIM was not associated with HSCC in any of the 3 HSCC categories. Herd SCC at the previous milk recording date had the largest contribution of all variables to the current HSCC in the LME model. This variable had a contribution of $0.60,0.61$, or 0.73 times the previous HSCC in the low, medium, and high HSCC categories, respectively. The percentage of cows with an individual SCC from 51,000 to 150,000 cells $/ \mathrm{mL}$, and those with SCC 151,000 to 250,000 cells $/ \mathrm{mL}$ at the previous test day had a significant contribution in the low HSCC category, but the latter was not a clear effect (Table 3). In the medium and high HSCC category of HSCC, all categories of SCC had a significant association (Table $3)$.

The significant management variables are presented in Table 4. None of the variables were significant in all 3 HSCC categories, whereas some variables had an opposite effect in different HSCC categories. Checking the dry cows visually for clinical mastitis (daily $-27,700$ cells $/ \mathrm{mL}$ or weekly $-24,600$ cells $/ \mathrm{mL}$ ), time after calving that the milk is added to the bulk tank $(-2,700$ cells/ $\mathrm{mL}$ per day), and locking cows in the head gates after milking during winter and summer period (13,500 cells/ $\mathrm{mL}$ vs. $-18,800$ cell $\mathrm{s} / \mathrm{mL}$ ) were only associated with HSCC in the low HSCC category. Feeding calves with milk of high SCC cows $(11,100$ cells $/ \mathrm{mL})$ was only manifest in the medium HSCC category. In the high HSCC category, registration of clinical mastitis cases $(-10,000$ cell $\mathrm{s} / \mathrm{mL})$, minimal days of treatment $(-5,500$ cells $/ \mathrm{mL}$ per day), and feeding calves with milk replacer $(-7,000$ cells $/ \mathrm{mL}$ ) demonstrated significant contributions. Checking the heifers for clinical mastitis weekly or daily was associated with a decreased HSCC in the medium and high HSCC category of 6,300 and 11,500 cells $/ \mathrm{mL}$ for the every day checking and 8,300 and 7,000 cells/ 


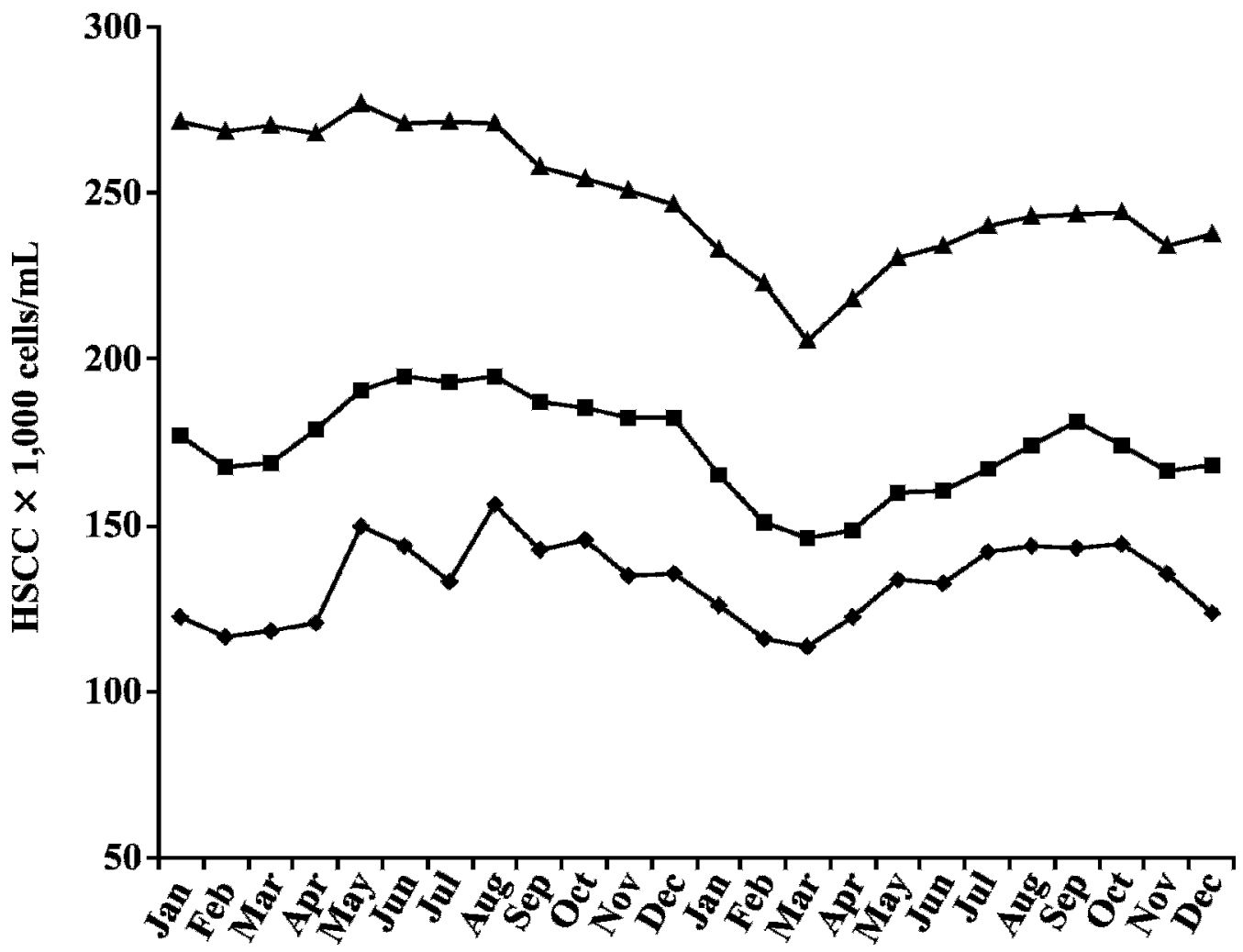

Month

$\rightarrow$ Low HSCC $\rightarrow$ Medium HSCC $\rightarrow$ High HSCC

Figure 1. Mean herd SCC (HSCC) of herds in the low $(<150,000$ cells $/ \mathrm{mL})$, medium $(150,000$ to $200,000 \mathrm{cells} / \mathrm{mL})$, and high $(>200,000$ cells/mL) HSCC category.

Table 2. Seasonal variables included in the final linear mixed effect model for 3 herd SCC (HSCC; $\times 1,000$ cells $/ \mathrm{mL}$ ) categories

\begin{tabular}{|c|c|c|c|c|c|c|}
\hline \multirow[b]{3}{*}{ Variable } & \multicolumn{6}{|c|}{ HSCC } \\
\hline & \multicolumn{2}{|c|}{$\begin{array}{c}<151 \\
(\mathrm{n}=81)\end{array}$} & \multicolumn{2}{|c|}{$\begin{array}{c}150 \text { to } 201 \\
(\mathrm{n}=86)\end{array}$} & \multicolumn{2}{|c|}{$\begin{array}{c}>200 \\
(\mathrm{n}=79)\end{array}$} \\
\hline & $\beta$ & $\mathrm{SE}$ & $\beta$ & $\mathrm{SE}$ & $\beta$ & SE \\
\hline Intercept & 64.0 & 16.6 & -20.8 & 42.0 & 47.7 & 39. \\
\hline Month 1 & $\operatorname{Ref}^{1}$ & & Ref & & $\operatorname{Ref}$ & \\
\hline Month 2 & -1.0 & 6.6 & -2.8 & 4.7 & 11.0 & 6.0 \\
\hline Month 3 & 3.4 & 6.0 & 3.2 & 4.3 & 10.1 & 5.5 \\
\hline Month 4 & 9.9 & 6.2 & 10.8 & 4.4 & 20.4 & 5.6 \\
\hline Month 5 & 24.5 & 6.1 & 18.7 & 4.4 & 27.9 & 5.6 \\
\hline Month 6 & 8.1 & 6.1 & 13.7 & 4.4 & 18.5 & 5.7 \\
\hline Month 7 & 7.4 & 6.1 & 14.0 & 4.4 & 22.0 & 5.6 \\
\hline Month 8 & 21.0 & 6.1 & 16.6 & 4.4 & 19.4 & 5.6 \\
\hline Month 9 & 6.3 & 6.1 & 12.7 & 4.3 & 12.2 & 5.6 \\
\hline Month 10 & 13.9 & 6.2 & 7.9 & 4.4 & 13.0 & 5.6 \\
\hline Month 11 & 1.1 & 6.0 & 4.0 & 4.3 & 6.1 & 5.4 \\
\hline Month 12 & 4.1 & 6.6 & 6.4 & 4.7 & 11.7 & 6.0 \\
\hline Year 1 & $-^{2}$ & & Ref & & Ref & \\
\hline Year 2 & - & - & -6.9 & 1.2 & -7.2 & 1.6 \\
\hline
\end{tabular}

${ }^{1}$ Ref $=$ referent.

${ }^{2}$ Deleted from the model via backward elimination based on the lowest Akaike information criterion value.
$\mathrm{mL}$ for every week checking, respectively. Opposite correlations were found between the low and medium category of HSCC for postmilking teat disinfection in the summer $(4,300$ vs. $-5,800$ cells $/ \mathrm{mL})$, and between the low and high category of HSCC for feeding calves fresh milk (10,300 vs. $-9,700$ cells $/ \mathrm{mL}$ ). To assess the contribution of the continuous variables in the LME model, Table 5 presents the mean value and contribution per significant variable in each category of HSCC.

\section{DISCUSSION}

The initial focus of this study was to quantify the contribution to HSCC of a large number of variables to support the interpretation of the current HSCC. Subsequently, the knowledge on fixed quantitative effects of management variables and seasonal effects together with the present variable individual SCC data can be used in modeling the HSCC of the next period for individual farms. We studied influence of variables in 3 categories of average HSCC: low, medium, and high. Surprisingly, during this study we detected that none 


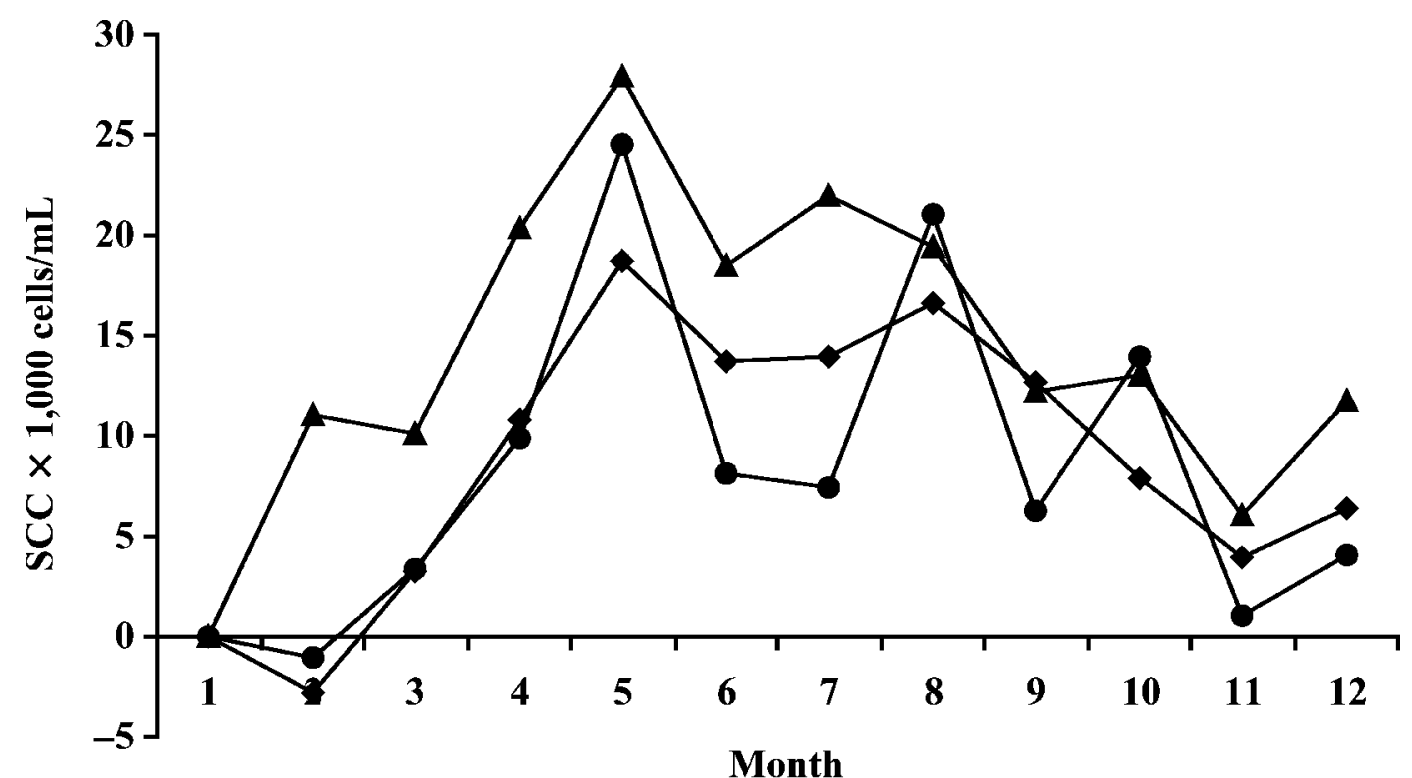

$\multimap-$ Low HSCC $\rightarrow$ Medium HSCC $\multimap$ High HSCC

Figure 2. Contribution of the variable month to the mean herd SCC (HSCC) in the low ( $<150,000$ cells $/ \mathrm{mL})$, medium (150,000 to 200,000 cells/mL), and high (>200,000 cells/mL) HSCC category.

of the variables were significantly associated with HSCC in all of the predefined categories, and some even had an opposite effect in 2 HSCC categories. This was not mentioned earlier in relevant literature, and therefore this study provides new insight into the way different variables influence SCC on the herd category. There are 3 possible explanations for the observed differences in association with HSCC among HSCC categories: 1) a difference in awareness of farmers in different HSCC categories, 2) a different approach or overestimation of the effects of management practices in the different HSCC categories, and 3) different pathogen distributions in the different HSCC categories.
All farms were visited 3 times to conduct a questionnaire; every year of the study there was a meeting for all participating farmers, a whole herd quarter milk sample collection was conducted, and the milking machine was evaluated during milking. Additional contact with the farmers occurred every 6 to 8 wk when clinical mastitis samples were collected. All these contacts may have increased the awareness of the effect of udder health management practices resulting in a decreasing HSCC in the medium and high HSCC category in the second year of the study (Figure 1).

The different approach of management practices among farms with a different BMSCC category is de-

Table 3. Herd characteristics in the final linear mixed effect model based on the lowest Akaike information criterion value for 3 herd SCC (HSCC; $\times 1,000$ cells $/ \mathrm{mL}$ ) categories

\begin{tabular}{|c|c|c|c|c|c|c|}
\hline \multirow[b]{3}{*}{ Variable } & \multicolumn{6}{|c|}{ Herd SCC } \\
\hline & \multicolumn{2}{|c|}{$\begin{array}{c}<151 \\
(\mathrm{n}=81)\end{array}$} & \multicolumn{2}{|c|}{$\begin{array}{c}150 \text { to } 201 \\
(\mathrm{n}=86)\end{array}$} & \multicolumn{2}{|c|}{$\begin{array}{c}>200 \\
(\mathrm{n}=79)\end{array}$} \\
\hline & $\beta$ & $\mathrm{SE}$ & $\beta$ & $\mathrm{SE}$ & $\beta$ & $\mathrm{SE}$ \\
\hline Average parity & -6.40 & 3.40 & 11.30 & 2.90 & 8.40 & 3.10 \\
\hline Average daily production $(\mathrm{kg})$ & -1 & - & -0.90 & 0.30 & 1.20 & 0.40 \\
\hline Herd size (lactating cows) & 0.20 & 0.01 & 0.10 & 0.00 & - & - \\
\hline Previous HSCC & 0.60 & 0.03 & 0.61 & 0.03 & 0.73 & 0.03 \\
\hline$\%$ cows SCC 0 to 50 previous HSCC & - & - & 0.79 & 0.36 & 1.32 & 0.33 \\
\hline$\%$ cows SCC 51 to 150 previous HSCC & 0.59 & 0.09 & 0.99 & 0.38 & 1.66 & 0.37 \\
\hline \% cows SCC 151 to 250 previous HSCC & 0.46 & 0.24 & 0.84 & 0.36 & 1.82 & 0.36 \\
\hline$\%$ cows SCC 251 to 500 previous HSCC & - & - & 1.15 & 0.33 & 1.52 & 0.33 \\
\hline
\end{tabular}

\footnotetext{
${ }^{1}$ Deleted from the model via backward elimination based on the lowest Akaike information criterion value.
} 
Table 4. Management practices in the final linear mixed effect model based on the lowest Akaike information criterion $(\mathrm{AIC})$ value for 3 herd SCC $(\mathrm{HSCC} ; \times 1,000$ cells $/ \mathrm{mL})$ categories

\begin{tabular}{|c|c|c|c|c|c|c|}
\hline \multirow[b]{3}{*}{ Variable } & \multicolumn{6}{|c|}{ HSCC } \\
\hline & \multicolumn{2}{|c|}{$\begin{array}{c}<151 \\
(\mathrm{n}=81)\end{array}$} & \multicolumn{2}{|c|}{$\begin{array}{l}150 \text { to } 201 \\
(\mathrm{n}=86)\end{array}$} & \multicolumn{2}{|c|}{$\begin{array}{c}>200 \\
(\mathrm{n}=79)\end{array}$} \\
\hline & $\beta$ & $\mathrm{SE}$ & $\beta$ & SE & $\beta$ & $\mathrm{SE}$ \\
\hline Clipping hair of all cows every year & $-^{1}$ & - & -8.8 & - & -8.4 & 3.8 \\
\hline Dry cows not visually checked for mastitis & $\operatorname{Ref}^{2}$ & & - & - & - & - \\
\hline Dry cows visually checked for mastitis every day & -27.7 & 8.1 & - & - & - & - \\
\hline Dry cows visually checked for mastitis every week & -24.6 & 7.6 & - & - & - & - \\
\hline Heifers not visually checked for mastitis & - & & Ref & - & Ref & - \\
\hline Heifers visually checked for mastitis every day & - & - & -6.3 & 4.2 & -11.5 & 3.4 \\
\hline Heifers visually checked for mastitis every week & - & - & -8.3 & 4.0 & -7.0 & 3.1 \\
\hline Wet premilking treatment & Ref & & - & - & - & - \\
\hline Dry premilking treatment & -9.1 & 2.6 & - & - & - & - \\
\hline Time after calving milk is added to bulk tank (d) & -2.7 & 0.8 & - & - & - & - \\
\hline Registration of clinical mastitis cases & - & - & - & - & -10.0 & 3.1 \\
\hline Minimal days of treatment of clinical mastitis & - & - & - & - & -5.5 & 1.6 \\
\hline Postmilking teat disinfection in summer & 4.3 & 1.9 & -5.8 & 2.6 & - & - \\
\hline Calves fed milk with high SCC & - & - & 11.1 & 2.5 & - & - \\
\hline Calves fed with fresh milk & 10.3 & 2.1 & - & - & -9.7 & 3.3 \\
\hline Calves fed with milk replacer & - & - & - & - & -7.0 & 3.3 \\
\hline $\begin{array}{l}\text { Cows not fed and not locked in head gates after } \\
\text { milking in the winter season }\end{array}$ & Ref & & - & - & - & - \\
\hline $\begin{array}{l}\text { Cows fed and not locked in head gates after } \\
\text { milking in winter season }\end{array}$ & 14.2 & 5.1 & - & - & - & - \\
\hline $\begin{array}{l}\text { Cows fed and locked in head gates after milking } \\
\text { in winter season }\end{array}$ & 13.5 & 4.1 & - & - & - & - \\
\hline $\begin{array}{l}\text { Cows not fed and not locked in head gates } \\
\text { after milking in the summer season }\end{array}$ & Ref & & - & - & - & - \\
\hline $\begin{array}{l}\text { Cows fed and not locked in head gates after } \\
\text { milking in summer season }\end{array}$ & -13.1 & 4.5 & - & - & - & - \\
\hline $\begin{array}{l}\text { Cows fed and locked in head gates after milking } \\
\text { in summer season }\end{array}$ & -18.8 & 3.9 & - & - & - & - \\
\hline
\end{tabular}

${ }^{1}$ Deleted from the model via backward elimination based on the lowest AIC value.

${ }^{2}$ Ref $=$ referent.

scribed in other studies on udder health management (Barnouin et al., 2004; De Vliegher et al., 2004; Rodrigues et al., 2005). Barkema et al. (1999) described a study on management style and its association with BMSCC and incidence rate of clinical mastitis and defined 2 clusters of farmers: a "quick and dirty" cluster

Table 5. Mean absolute contribution of the continuous herd characteristics and management practices variables in the final linear mixed effect (LME) model for 3 herd SCC $(\mathrm{HSCC} ; \times 1,000$ cells $/ \mathrm{mL})$ categories

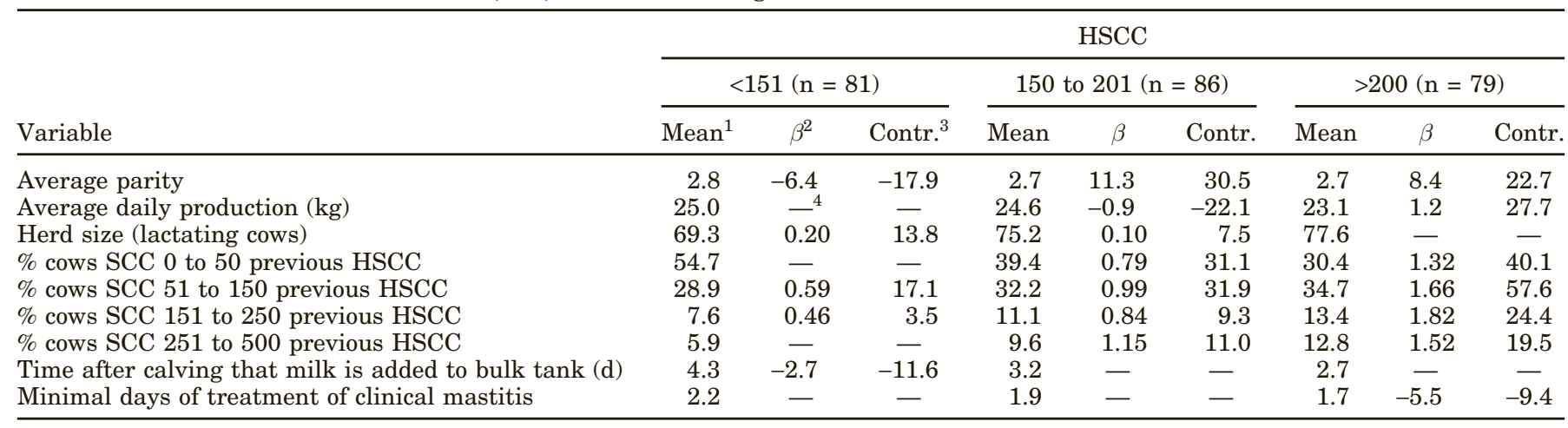

\footnotetext{
${ }^{1}$ Mean value of the variable.

${ }^{2} \beta$ value of the LME model.

${ }^{3}$ Contr. = mean absolute contribution of the variable (mean value times the $\beta$ value of the LME model).

${ }^{4} \beta$ value not significant in the LME model.
} 
and a "clean and accurate" cluster. Farmers with a low BMSCC were more precise than fast, whereas farmers with a high BMSCC showed the opposite attitude. Tarabla and Dodd (1990) carried out a survey on associations between farmers' personal characteristics, management practices, and farm performances (milk yield and quality) and reported that the variables related to farmers' attitude and socio-demographic profile explained a similar or greater amount of the farm performance than the group of management variables. These studies confirmed that the influence of the farmers' attitude is underestimated, and the effect of management practices is perhaps overestimated. The third possible explanation of different pathogen distributions is based on studies that found different pathogens on different levels of individual or HSCC (Schukken et al., 1990; De Haas et al., 2004). These pathogen distributions are not included in the model, but determination of the pathogen distribution is very important when giving recommendations on farm-specific udder health management. Also, the large monthly fluctuations could not be explained throughout this study. Two possible explanations for these fluctuations could again be the pathogen distribution and the influence of temperature.

Apart from those 3 possible explanations, awareness, approach, and pathogen distributions, logical pathways for the absence of effects or opposite directions for several management practices are not always easy to provide. Also, a remarkable outcome was found for locking the cows in head gates after milking. This management practice had different effects during different seasons (winter or summer). So far no biological reason for the outcome can be provided. The authors suggest that more research regarding the influences on different levels of HSCC including pathogen distribution is needed, especially because all outcomes were compared with studies that used the BMSCC as a dependent variable instead of the HSCC parameter.

The parameter used in this study, HSCC, was different from the frequently used BMSCC. Originally, BMSCC was introduced as a quality parameter by dairy processors. As a consequence of not including milk of all cows in the bulk milk tank the BMSCC will not always be a reliable reflection of the SCC of all cows in a herd. On that account, in this study only the individual SCC were used to calculate the HSCC. In comparison with the original study of Barkema et al. (1998a) on management practices, which uses the BMSCC parameter instead of the HSCC parameter, some inexplicable differences in significant management practices were found. The most important management practices between herds with a low BMSCC of the original study and the other herds were postmilking teat disinfection (only a difference between the low and medium HSCC category in the current study), duration of treatment of clinical mastitis cases (only an effect in the high HSCC category of the current study), and drying after wet premilking treatment (no effect in the current study). Not finding an association between HSCC and a management practice within a certain HSCC category, however, does not automatically imply that this management practice would not have an effect on cow- and herd-category SCC. If the proportion of herds that has adopted this management practice is low or high, a larger number of herds would need to be included in the study or a different study design would be necessary to increase the power of the study and find a significant association with HSCC. The low number of significant management practices and in some cases their small contribution to the total HSCC imply the need for a profound study on these particular management practices. The low number of significant management practices and in some cases their small contribution to the total HSCC implies the need for a profound study on these particular management practices. The design of this study, particularly the classification of all herds within a defined category, could prevent finding important significant management practices. Therefore, a subsequent study should include farms with a less constant level of HSCC and a more intensive monitoring of the management practices. Regarding the quantification of the significant management variables, this study provides a range for each HSCC category based on the accepted practices on the individual farm. The range between the sum of increasing or decreasing significant management practices was $99,300,34,000$, and 43,700 cell $\mathrm{s} / \mathrm{mL}$ in the low, medium, and high HSCC category, respectively. In total this range is rather large for the low HSCC category and small for the medium and high HSCC category. A general explanation for the difference in range could be the accuracy of the farmers to carry out the necessary management practices in herd within the high HSCC category.

\section{CONCLUSIONS}

None of the management variables was significantly associated with HSCC in all 3 HSCC categories, whereas some variables had an opposite effect between HSCC categories. This suggests that care must be taken in drawing generalized conclusions for the possible effectiveness of, for example, management changes aimed at reducing HSCC for a particular farm. This also suggests the need for a reinvestigation of various management practices factors and their effects on HSCC. 


\section{ACKNOWLEDGMENT}

The authors would like to thank the Dutch Breeding Organization for providing the individual milk production recording data used in this study.

\section{REFERENCES}

Akaike, H. 1973. Information theory and an extension of the maximum likelihood principle. Pages 267-281 in Second Int. Symp. Inf. Theory, Budapest, Hungary. Tsahkadsor, Armenia.

Barkema, H. W., Y. H. Schukken, T. J. G. M. Lam, M. L. Beiboer, G. Benedictus, and A. Brand. 1998a. Management practices associated with low, medium, and high somatic cell counts in bulk milk. J. Dairy Sci. 81:1917-1927.

Barkema, H. W., Y. H. Schukken, T. J. G. M. Lam, M. L. Beiboer, G. Benedictus, and A. Brand. 1999. Management practices associated with the incidence rate of clinical mastitis. J. Dairy Sci. 82:1643-1654.

Barkema, H. W., Y. H. Schukken, T. J. G. M. Lam, M. L. Beiboer, H. Wilmink, G. Benedictus, and A. Brand. 1998b. Incidence of clinical mastitis in dairy herds grouped in three categories by bulk milk somatic cell counts. J. Dairy Sci. 81:411-419.

Barnouin, J., M. Chassagne, S. Bazin, and D. Boichard. 2004. Management practices from questionnaire surveys in herds with very low somatic cell score through a national mastitis program in France. J. Dairy Sci. 87:3989-3999.

De Haas, Y., R. F. Veerkamp, H. W. Barkema, Y. T. Gröhn, and Y. H. Schukken. 2004. Associations between pathogen-specific cases of clinical mastitis and somatic cell count patterns. J. Dairy Sci. 87:95-105.

De Vliegher, S., H. Laevens, H. W. Barkema, I. R. Dohoo, H. Stryhn, G. Opsomer, and A. de Kruif. 2004. Management practices and heifer characteristics associated with early lactation somatic cell count of Belgian dairy heifers. J. Dairy Sci. 87:937-947.

Goodger, W. J., T. Farver, J. Pelletier, P. Johnson, G. de Snayer, and J. Galland. 1993. The association of milking management practices with bulk tank somatic cell counts. Prev. Vet. Med. 15:235-251.

Green, M. J., A. J. Bradley, H. Newton, and W. J. Browne. 2006. Seasonal variation of bulk milk somatic cell counts in UK dairy herds: Investigations of the summer rise. Prev. Vet. Med. 74:293-308.
Igono, M. O., H. D. Johnson, B. J. Steevens, W. A. Hainen, and M. D. Shanklin. 1988. Effect of season on milk temperature, milk growth-hormone, prolactin, and somatic-cell counts of lactating cattle. Int. J. Biometeorol. 32:194-200.

Jayarao, B. M., S. R. Pillai, A. A. Sawant, D. R. Wolfgang, and N. V. Hegde. 2004. Guidelines for monitoring bulk tank milk somatic cell and bacterial counts. J. Dairy Sci. 87:3561-3573.

Lievaart, J. J., W. D. J. Kremer, and H. W. Barkema. 2007. Comparison of bulk milk, yield-corrected, and average somatic cell counts as parameters to summarize the subclinical mastitis situation in a dairy herd. J. Dairy Sci. 90:4145-4148.

Olde Riekerink, R. G., H. W. Barkema, S. Veenstra, D. E. Poole, R. T. Dingwell, and G. P. Keefe. 2006. Prevalence of contagious mastitis pathogens in bulk tank milk in Prince Edward Island. Can. Vet. J. 47:567-572.

Pinheiro, J. C., and D. M. Bates. 2000. Mixed effects model in S and S-Plus. Springer, New York, NY.

Pitkälä, A., M. Haveri, S. Pyörälä, V. Myllys, and T. HonkanenBuzalski. 2004. Bovine mastitis in Finland 2001. Prevalence, distribution of bacteria, and antimicrobial resistance. J. Dairy Sci. 87:2433-2441.

R Development Core Team. 2005. R: A language and environment for statistical computing. R Foundation for Statistical Computing, Vienna, Austria. http://www.R-project.org Accessed Oct. 2006.

Rodrigues, A. C. O., D. Z. Caraviello, and P. L. Ruegg. 2005. Management of Wisconsin dairy herds enrolled in milk quality teams. J. Dairy Sci. 88:2660-2671.

Sampson, R. 2006. Dairy farmer's response to the quality bonus program. Proc. NMC Summer meeting, August 9-10, 2006, Charlottetown, Prince Edward Island, Canada. NMC, Verona, WI.

Schukken, Y. H., J. Buurman, A. Brand, D. van der Geer, and F. J. Grommers. 1990. Population dynamics of bulk milk somatic cell counts. J. Dairy Sci. 73:1343-1350.

Sewalem, A., G. J. Kistemaker, F. Miglior, and B. J. Van Doormaal. 2006. Analysis of inbreeding and its relationship with functional longevity in Canadian dairy cattle. J. Dairy Sci. 89:2210-2216.

Tarabla, H. D., and K. Dodd. 1990. Associations between farmers personal characteristics, management-practices and farm performance. Br. Vet. J. 146:157-164.

Valde, J. P., O. Osteras, and E. Simensen. 2005. Description of herd level criteria for good and poor udder health in Norwegian dairy cows. J. Dairy Sci. 88:86-92.

Wilson, D. J., H. H. Das, R. N. Gonzalez, and P. M. Sears. 1997. Association between management practices, dairy herd characteristics, and somatic cell count of bulk tank milk. J. Am. Vet. Med. Assoc. 210:1499-1502. 